\title{
Michał Leciak
}

Uniwersytet Mikołaja Kopernika, Toruń

leciak@umk.pl

ORCID: https://orcid.org/0000-0002-2462-5545

\section{Image enhancing drugs $\mathrm{w}$ sporcie - analiza zjawiska i karnoprawnych środków jego zwalczania}

\author{
http://dx.doi.org/10.12775.SIT.2021.027
}

\section{Wprowadzenie}

Do niekwestionowanych patologii współczesnego sportu można zaliczyć zjawisko dopingu. Wprawdzie pojawiło się ono już na wczesnych etapach rozwoju tej formy aktywności człowieka, ale wraz $\mathrm{z}$ jej narastającą profesjonalizacją oraz poddaniem jej regułom gospodarki wolnorynkowej dążenie do zwiększenia możliwości zwycięstwa w ramach sportowej rywalizacji stało się nadzwyczaj silne. Myliłby się jednak ten, kto uważa, że aktualnie doping należy utożsamiać $z$ takimi substancjami, które wpływają na zwiększenie wydolności organizmu zawodnika. Dotyczy on bowiem co najmniej równie często także tych substancji, których stosowanie prowadzi m.in. do redukcji masy ciała, zwiększenia masy mięśniowej czy tężyzny fizycznej ${ }^{1}$. Taki efekt niektórych kategorii substancji zabro-

1 Zob. R. Mooney, P. Simonato, R. Ruparelia, A. Roman-Urrestarazu, G. Martinotti, O. Corazza, The use of supplements and performance and image enhancing drugs in fitness settings: A exploratory cross-sectional investigation in the United Kingdom, „Human Psychopharmacology: Clinical and Experimental” 2017, No. 3, s. 2. 
nionych doprowadził częściowo do tego, że zjawisko dopingu przekroczyło wyraźnie granice aren sportowych, pojawiając się w miejscach, w których współzawodnictwo nie stanowi już kluczowych elementów aktywności. Coraz częściej określone formy substancji zabronionych pojawiają się bowiem w siłowniach, klubach fitness lub innych miejscach przeznaczonych do podobnych form aktywności fizycznej człowieka. Proceder tego typu przybiera w ostatnich dekadach wyraźnie na sile, generując szerokie spektrum problemów, począwszy od tych związanych ze zdrowiem publicznym, a skończywszy choćby na kwestii znacznego zaangażowania przestępczości zorganizowanej, m.in. w obszarze nielegalnej produkcji oraz dystrybucji takich środków. W ten sposób stosowanie pewnych substancji zabronionych, zastrzeżone wcześniej przede wszystkim dla sportu profesjonalnego, sprawiło, że doping stał się zjawiskiem masowym, obejmując sport uprawiany amatorsko oraz inne pokrewne formy rekreacji.

\section{Charakterystyka pojęcia image enhancing drugs w sporcie}

W literaturze zagranicznej powszechnie używa się pewnego zbiorczego pojęcia performance and image enhancing drugs (PIED) na określenie substancji zabronionych w sporcie. Co znamienne, na ogół potoczne rozumienie dopingu w sporcie obejmuje raczej te z nich, które mogą bezpośrednio wpływać na wynik lub przebieg sportowego współzawodnictwa (tzw. performance enhancing drugs). Rzadziej natomiast identyfikuje się je $z$ tymi środkami, których stosowanie ma służyć generalnie - przede wszystkim - poprawie wyglądu, głównie poprzez wzrost tkanki mięśniowej lub redukcję masy ciała (tzw. image enhancing drugs).

Bardziej szczegółową analizę wskazanego w tytule niniejszego opracowania określenia należy rozpocząć jednak od wyjaśnienia wspomnianego pojęcia dopingu w sporcie, obejmującego również drugą ze wspomnianych kategorii substancji. Na początek wypada wspomnieć, że samo pojęcie sportu ma w polskim ustawodawstwie definicję legalną. Daje ona niezwykle szerokie jego rozumienie, 
pozwalające umieścić w jego ramach także aktywność realizowaną m.in. w klubach fitness czy siłowniach. Została ona zamieszczona w art. 2 ust. 1 i la Ustawy $z$ dnia 25 czerwca 2010 r. o sporcie ${ }^{2}$. Podejmując się natomiast próby zdefiniowania dopingu w sporcie, należy zwrócić na początek uwagę na regulacje prawa międzynarodowego $^{3}$. Na gruncie Konwencji antydopingowej Rady Europy ${ }^{4}$ za doping uznano „podawanie sportowcom lub używanie przez nich farmakologicznych klas środków dopingujących oraz stosowanie metod dopingowych" (art. 2 ust. 1 lit. a) ${ }^{5}$. Zmianę w sposobie definiowania dopingu przyniosło jednak przyjęcie w 2003 r. Światowego kodeksu antydopingowego (dalej: WADC) ${ }^{6}$. Od dnia 1 stycznia 2021 r. obowiązuje jego wersja po nowelizacji z 2019 r. W art. 1 WADC określono doping jako wystąpienie jednego lub więcej naruszeń regulaminu antydopingowego określonych w art. 2.1-2.11 $\mathrm{WADC}^{7}$. W ten sposób definicja dopingu w sporcie objęła niezwykle

${ }^{2}$ Tekst jednolity: Dz.U. z 2020 r. poz. 1133 ze zm. W ujęciu art. 2 pkt 1 i la ustawy: „Sportem są wszelkie formy aktywności fizycznej, które przez uczestnictwo doraźne lub zorganizowane wpływają na wypracowanie lub poprawienie kondycji fizycznej i psychicznej, rozwój stosunków społecznych lub osiągnięcie wyników sportowych na wszelkich poziomach” (art. 2 ust. 1). „Za sport uważa się również współzawodnictwo oparte na aktywności intelektualnej, którego celem jest osiągnięcie wyniku sportowego" (art. 2 ust. 1a).

3 Zob. R. Piechota, Reguły antydopingowe $w$ prawie międzynarodowym, „Studia Iuridica Toruniensia” 2010, nr 6, s. 158.

${ }^{4}$ Konwencja antydopingowa Rady Europy, sporządzona w Strasburgu w dniu 16 listopada 1989 r. (Dz.U. z 2001 r. Nr 15, poz. 149 ze zm.).

5 Tę definicję dopełniono, wyjaśniając w art. 2 ust. 1 lit. b pojęcia farmakologicznych klas środków dopingujących oraz metod dopingowych poprzez odwołanie do ich list tworzonych przez międzynarodowe organizacje sportowe, a następnie zatwierdzanych przez Grupę Monitorującą wskazanej Konwencji (zob. R. Piechota, w: Prawo sportowe, red. M. Leciak, Warszawa 2018, s. 347).

6 Światowy kodeks antydopingowy (WADC), przyjęty przez Światową Agencję Antydopingową (WADA) w dniach 3-5 marca 2003 r. w Kopenhadze (wersja obowiązująca od dnia 1 stycznia 2021 r.); zob. szerzej na ten temat: A. Wach, Harmonizacja światowego prawa antydopingowego $z$ polskiej perspektywy, „Państwo i Prawo” 2007, nr 8, s. 34 i n.; U. Haas, Background to the World Anti-Doping Code 2015, w: Doping in sport and the law, eds. U. Haas, D. Healey, Oxford 2016, s. 19 i n.

7 Wśród naruszeń regulaminu antydopingowego wskazano takie zachowania, jak: obecność substancji zabronionej lub jej metabolitów lub markerów w próbce fizjologicznej zawodnika (art. 2.1); użycie lub próba użycia przez 
szeroki katalog zachowań o zróżnicowanej naturze i różnym stopniu zagrożenia dla takich dóbr prawnych jak uczciwość sportowej rywalizacji oraz równość szans ${ }^{8}$. Przede wszystkim $z$ uwagi na tego typu elementy wprowadzono system kar dyscyplinarnych zrelacjonowanych względem konkretnych naruszeñ ${ }^{9}$. Tak ukształtowana definicja dopingu w sporcie została zarazem uzupełniona przez prawodawcę o tzw. człon pragmatyczny. Należy go wiązać z powołaniem „Listy substancji i metod zabronionych”, która jest obowiązkowym standardem międzynarodowym, będącym częścią Światowego Programu Zwalczania Dopingu w Sporcie. Corocznie następuje jej aktualizacja w efekcie konsultacji przeprowadzonych przez Światową Agencję Antydopingową (WADA) ${ }^{10}$.

zawodnika substancji zabronionej lub metody zabronionej (art. 2.2); unikanie lub odmowa oddania próbki lub też niestawienie się w celu oddania próbki (art. 2.3); naruszenie wymagań dotyczących wskazania miejsca pobytu (art. 2.4); manipulowanie lub próba manipulowania przez zawodnika lub inną osobę jakąkolwiek częścią kontroli antydopingowej (art. 2.5); posiadanie substancji zabronionej lub użycie metody zabronionej przez zawodnika lub personel pomocniczy zawodnika (art. 2.6); obrót lub próba obrotu jakąkolwiek substancją zabronioną lub metodą zabronioną przez zawodnika lub inną osobę (art. 2.7); podanie lub próba podania przez zawodnika lub inną osobę dowolnemu zawodnikowi podczas zawodów jakiejkolwiek substancji zabronionej lub metody zabronionej, lub też podanie lub próbę podania dowolnemu zawodnikowi poza zawodami jakiejkolwiek substancji lub metody, która jest zabroniona poza zawodami (art. 2.8); współudział lub próba współudziału zawodnika lub innej osoby (art. 2.9); zabroniony związek zawodnika lub innej osoby (art. 2.10); działania zawodnika lub innej osoby, mające na celu zniechęcenie do powiadomienia władz lub wzięcie odwetu za powiadomienie władz (art. 2.11) - zob. https://www.antydoping.pl/wp-content/uploads/2020/12/\%C5\%9Awiatowy-Kodeks-Antydopingowy-2021-wersja-PL.pdf (dostęp: 1.07.2021 r.).

8 Zob. R. Piechota, w: Prawo sportowe, s. 350.

${ }^{9}$ Zob. szerzej A. Wach, Światowy Kodeks Antydopingowy - aspekty prawne, „Sport Wyczynowy” 2003, nr 7-8, s. 40 i n.

10 Obowiązująca od dnia 1 stycznia 2021 r. lista obejmuje substancje i metody zabronione w każdym czasie (w tym: SO - substancje niezatwierdzone; S1 - środki anaboliczne; S2 - hormony peptydowe, czynniki wzrostu, substancje pokrewne i mimetyki; S3 - beta2-agoniści; S4 - modulatory hormonów i metabolizmu; S5 - diuretyki i środki maskujące; M1, M2, M3 środki maskujące), substancje i metody zabronione podczas zawodów (w tym: S6 - stymulanty; S7 - narkotyki; S8 - kanabinoidy; S9 - glikokortykoidy) oraz substancje zabronione w niektórych sportach (P1 - beta-blokery). 
Tego typu rozumienie dopingu w sporcie znalazło swoje odbicie w innych aktach prawa międzynarodowego. Dotyczy to przede wszystkim przepisów Konwencji antydopingowej UNESCO (art. 2) ${ }^{11}$. Co ważne, odnosi się to również do polskiego ustawodawstwa, albowiem posłużono się tak ukształtowaną definicją najpierw na gruncie art. 43 ust. 1-6 Ustawy $z$ dnia 25 czerwca 2010 r. o sporcie $^{12}$, a potem $w$ ramach przepisów Ustawy $z$ dnia 21 kwietnia 2017 r. o zwalczaniu dopingu w sporcie ${ }^{13}$ (dalej: ustawa antydopingowa).

Obowiązująca w polskim ustawodawstwie definicja dopingu w sporcie odwołuje się do wspomnianych pojęć substancji zabronionej oraz metody zabronionej, których wyjaśnienie następuje poprzez odesłanie do załącznika nr 1 do Konwencji antydopingowej UNESCO (art. 2 pkt 1 i 2 ustawy antydopingowej). Sama $z$ kolei definicja dopingu w sporcie została skonstruowana na wzór tej zamieszczonej w WADC ${ }^{14}$ i opiera się wyraźnie na enumeratywnym wyliczeniu zachowań mogących stanowić doping w sporcie (art. 3 ust. 1 pkt 1-10 ustawy antydopingowej).

Wyjaśnienie pojęcia dopingu w sporcie w kontekście podjętej tematyki pozwala wreszcie na odniesienie się do rozumienia zwrotu image enhancing drugs ${ }^{15}$. Efekt, do jakiego dążą osoby stosujące omawiane substancje, może się wiązać $z$ chęcią redukcji masy ciała, zwiększenia masy mięśniowej, zbudowania tężyzny fizycznej czy

11 Międzynarodowa konwencja o zwalczaniu dopingu w sporcie, sporządzona w Paryżu w dniu 19 października 2005 r. (Dz.U. z 2007 r. Nr 142, poz. 999 ze zm.).

12 Dz.U. Nr 127, poz. 857 ze zm.

13 Dz.U. poz. 1051 ze zm.

${ }^{14}$ Zob. Uzasadnienie rządowego projekt ustawy o zwalczaniu dopingu w sporcie $z$ dnia 28 grudnia 2016 r., druk nr 1184, s. 3 i n.

15 Na marginesie należy zaznaczyć, że nierzadko można również natrafić w zagranicznej literaturze na określenie istotnie pokrewne znaczeniowo, tj. appearance enhancing drugs (zob. m.in. T.B. Hildebrandt, E. Varangis, J.K. La, Appearance and Performance Enhancing Drug Use, w: The Oxford Handbook of Sport and Performance Psychology, ed. S.M. Murphy, Oxford 2012, s. 545 i n.; B.T. Karazsia, J.H. Crowther, R. Galioto, Undergraduate men's use of performance- and appearance-enhancing substances: An examination of the gateway hypothesis, „Psychology of Men \& Masculinity” 2012, No. 2, s. 129 i n.). 
nawet zmiany koloru skóry. Mogą być one przyjmowane doustnie, poprzez iniekcję, a nawet aplikowane jako maść czy krem ${ }^{16}$.

Zdecydowanie najszerszą i najbardziej rozpowszechnioną grupę stanowią sterydy anaboliczno-androgenne. Ich regularne stosowanie powoduje przyrost masy ciała, zwiększenie siły i wytrzymałości, a małe dawki mogą wywoływać zachowania agresywne. Wśród omawianych substancji dominują pochodne testosteronu ${ }^{17}$. W ich katalogu umieszcza się również środki anaboliczne niebędące sterydami. Wykorzystuje się przy tym często hormon wzrostu, którego stosowanie prowadzi do przyrostu mięśni, ale jednocześnie także m.in. organów wewnętrznych. Podobne efekty należy wiązać ze stosowaniem insuliny ${ }^{18}$. Niezwykle popularne pozostają też substancje ergogeniczne i termogeniczne. Te pierwsze obejmują szerokie spektrum środków, których stosowanie ma zwiększać wydolność organizmu. Wśród nich dominują tzw. suplementy sportowe, np. kreatyna, arginina czy kofeina. $Z$ kolei substancje o działaniu termogenicznym wywołują przede wszystkim efekt spalania tłuszczu. $Z$ jednej strony pojawiają się $\mathrm{w}$ tym zakresie środki zabronione przez WADA (np. geranium), $z$ drugiej natomiast substancje termogeniczne pozostają często zanieczyszczone innymi substancjami zabronionymi ${ }^{19}$. Do katalogu image enhancing drugs włącza się także czasami w literaturze inne kategorie substancji, jak choćby diuretyki, których zadaniem jest redukcja masy ciała ${ }^{20}$.

16 Zob. M. Lusetti, M. Licata, E. Siligardi, A. Bonsignore, C. Palmiere, Appearance/Image- and Performance-Enhancing Drug Users. A Forensic Approach, „The American Journal of Forensic Medicine and Pathology” 2018, No. 4, s. 325-329.

17 Z. Przybylski, Medyczne aspekty dopingu w sporcie, w: Prawne problemy dopingu w sporcie, red. A.J. Szwarc, Poznań 1992, s. 29-30.

18 Zob. K. Sas-Nowosielski, Doping nie tylko $w$ sporcie. Przyczyny. Skutki. Przeciwdziałanie, Katowice 2002, s. 147-148.

19 Zob. J.M. Martinez-Sanz, I. Sospedra, Ch. Mañas Ortiz 3, E. Baladía, A. Gil-Izquierdo, R. Ortiz-Moncada, Intended or Unintended Doping? A Review of the Presence of Doping Substances in Dietary Supplements Used in Sports, „Nutrients” 2017, No. 9, s. 16 i n.

20 Por. A.B. Cadwallader, X. de la Torre, A. Tieri, F. Botrè, The abuse of diuretics as performance-enhancing drugs and masking agents in sport doping: 


\section{Ewolucja image enhancing drugs w sporcie}

Niewątpliwie doping stanowi „ciemną stronę” współczesnego sportu, obok takich przede wszystkim jego patologii jak korupcja, przemoc stadionowa czy rasizm. Jest on obecny zapewne od samego początku tego typu aktywności fizycznej człowieka, wszak dążenie do kontroli organizmu (np. zmęczenia) pojawiało się w większości kręgów kulturowych. Znane już z czasów antycznych przypadki stosowania dopingu wiązały się jednak przede wszystkim $z$ takim instrumentalnym używaniem określonych substancji, którego celem było zwiększenie szans zwycięstwa w ramach sportowej rywalizacji. Zażywano alkohol, mięso lub krew zwierząt czy jądra byków ${ }^{21}$. Wprawdzie w późniejszym okresie pojawiły się nowe substancje o tego typu działaniu, jak choćby syntetyczne środki odurzające, to jednak wciąż cel ich stosowania pozostawał co do zasady ten sam $^{22}$. Momentem przełomowym $-z$ perspektywy omawianej problematyki - stało się natomiast pojawienie się w sporcie profesjonalnym substancji, których stosowaniu miał towarzyszyć zgoła odmienny już efekt, a związany z przyrostem masy mięśniowej czy zwiększeniem siły. Gwałtowny wzrost zainteresowania stosowaniem środków anabolicznych oraz hormonów, które tego typu cel mogą realizować, przypadł przede wszystkim na okres I i II wojny światowej. Zdobyta w ten sposób wiedza i doświadczenia zostały następnie szeroko zdyskontowane na arenach sportowych. Jednym $z$ pierwszych tego przykładów było prawdopodobne używanie syntetycznego testosteronu przez niemieckich zawodników podczas igrzysk w Berlinie w 1936 r. ${ }^{23}$ Stosowanie hormonów i sterydów zaczęło przeżywać wyraźny rozkwit po II wojnie światowej, kiedy

pharmacology, toxicology and analysis, „British Journal of Pharmacology” 2010, No. 1, s. 2 i n.

21 Zob. R.K. Müller, History of doping and doping control, w: Doping in Sports, eds. D. Thieme, P. Hemmersbach, Berlin 2010, s. 2.

22 Zob. K. Sas-Nowosielski, op.cit., s. 15 i n.; M. Łuczak, Doping in Sport: The Case of Fencing, „Central European Journal of Sport Sciences and Medicine" 2016, No. 1, s. 135.

23 Zob. M. Mędras, P. Jóźków, Zastosowanie testosteronu i steroidów an- 
to wkroczyło początkowo przede wszystkim w świat tzw. sportów siłowych. Wyraźną tego egzemplifikację może stanowić używanie testosteronu przez zawodników rosyjskich w ramach dyscyplin związanych $\mathrm{z}$ podnoszeniem ciężarów podczas igrzysk w Helsinkach w $1952 \mathrm{r}^{24}$ Generalnie stosowanie sterydów anabolicznych uległo silnemu rozpowszechnieniu w krajach Europy Wschodniej, w ramach funkcjonujących na szeroką skalę programów dopingowych, np. w NRD. Pierwsze kontrole antydopingowe na obecność sterydów pojawiły się jednak dopiero podczas igrzysk w Montrealu w 1976 r., czego efektem były pozytywne wyniki testów niemal wyłącznie u zawodników podnoszących ciężary ${ }^{25}$.

W latach 60. XX w. zjawisko stosowania omawianych substancji zaczęło już natomiast przenikać do świata sportu amatorskiego, by przybrać zdecydowanie na sile w latach 80 . Wówczas wyjątkowo wyraźnie w obszarze sportu masowego oraz rekreacji ruchowej pojawiły się przede wszystkim sterydy anaboliczne oraz hormony wzrostu, a ich używanie wpisało się na stałe w środowiska siłowni czy klubów fitness ${ }^{26}$. Współcześnie już faktu ich powszechnego występowania w tego typu miejscach nie sposób kwestionować.

\section{Współczesne zagrożenia}

Nie powinno być wątpliwości, że używanie omawianych kategorii substancji zabronionych stanowi już nie tylko patologię sportu, ale zarazem poważny problem społeczny. Poszukując powodów gwałtownego rozwoju tego zjawiska, zauważa się, że korzystanie ze wspomnianych substancji zabronionych wynika m.in. z ludzkiej natury i dążenia do doskonałości. Ich stosowanie może bowiem wpływać na budowę masy mięśniowej, atrakcyjny wygląd, zdol-

drogenno-anabolicznych $w$ sporcie, „Polish Journal of Endocrinology” 2009, nr 3, s. 205.

24 Zob. M. Kremenik, S. Onodera, M. Nagao, O. Yuzuki, S. Yonetani, A historical timeline of doping in the Olympics (Part I 1896-1968), „Kawasaki Journal of Medical Welfare" 2006, No. 1, s. 21.

25 Zob. K. Sas-Nowosielski, op.cit., s. 26.

26 Ibidem, s. 95. 
ności motoryczne, pociąg seksualny itd. ${ }^{27}$ Cechy te są szczególnie ważne dla młodych ludzi, stąd też oni właśnie bywają głównymi odbiorcami i konsumentami tych substancji.

Zasadniczy problem związany $\mathrm{z}$ rozwojem rynku omawianych środków wynika $z$ zagrożenia, jakie stwarzają one dla życia i zdrowia jednostki oraz ogółu społeczeństwa. Ich stosowanie może m.in. powodować zwyrodnienie mięśnia sercowego, nadciśnienie, zaburzenia krzepliwości krwi, cukrzycę, zahamowanie wzrostu w wieku dojrzewania, impotencję, trwałą ginekomastię u mężczyzn, zwiększać ryzyko zakażenia, np. HIV, a także prowadzić do depresji, paranoi, agresji i przemocy ${ }^{28}$. Do wcale nierzadkich należą zatem przypadki śmiertelne ${ }^{29}$.

Szerokie badania na temat zastosowania omawianej kategorii substancji zabronionych przeprowadzono przede wszystkim w Wielkiej Brytanii, we Włoszech oraz w Australii. Wyniki tego typu krajowych analiz pozostają co do zasady zbliżone. Wśród powodów zażywania takich środków zdecydowanie dominuje chęć poprawy swojego wizerunku, a najczęściej stosowanymi substancjami pozostają sterydy anaboliczne. Co istotne, zwracając uwagę na problem ich nadużywania wśród młodych ludzi - najczęściej w wieku 20-24 lata - słusznie wskazuje się na swoistą „bombę z opóźnionym zapłonem"30. Szacuje się, że w samej Wielkiej Brytanii liczba osób mogących używać takich substancji może sięgać 1 miliona. Kon-

27 Zob. D. Hauw, J. Bilard, Understanding Appearance-Enhancing Drug Use in Sport Using an Enactive Approach to Body Image, „Frontiers in Psychology” 2017, No. 8, s. 2 i n.

28 Zob. L.H. Duntas, V. Popovic, Hormones as doping in sports, „Endocrine” 2012, No. 2, s. 304 i n.; F. Mazzeo, A. Ascione, Anabolic androgenic steroids and doping in sport, "Medicina Sportiva. Journal of the Romanian Sports Medicine Society" 2013, No. 1, s. 2014 i n.; Z. Przybylski, op.cit., s. 25 i n.; K. Sas-Nowosielski, op.cit., s. 141-147.

29 Zob. L. Paoli, A. Donati, The supply of doping products and the potential of criminal law enforcement in anti-doping: an examination of Italy's experience, Leuven 2013, s. 6.

30 Zob. Image and Performance Enhancing Drugs. UKAD status report on IPEDs in the UK, London 2019, s. 5, https://www.ukad.org.uk/sites/default/ files/2020-01/UKAD\%20IPED\%20Report\%20FINAL.pdf (dostęp: 1.07 .2021 r.); por. L. Paoli, A. Donati, The supply, s. 5-6. 
sekwencje tego zjawiska będą bowiem stawać się z czasem coraz bardziej odczuwalne w obszarze zdrowia publicznego ${ }^{31}$.

Jednocześnie wyniki powyższych badań ujawniły istnienie w skali globalnej zorganizowanych sieci dostaw i dystrybucji image enhancing drugs. Wśród państw, $z$ obszaru których trafiają one najczęściej do Europy, wymienia się Chiny, Hongkong, Indie, Stany Zjednoczone oraz Tajlandię ${ }^{32}$. Tytułem przykładu można tylko dodatkowo wskazać, że na granicach zewnętrznych Wielkiej Brytanii corocznie jest zatrzymywanych około 5 milionów dawek sterydów. Równie wysokie wartości w tym zakresie, ulegające systematycznemu wzrostowi, odnotowuje się choćby we Włoszech ${ }^{33}$ czy Australii ${ }^{34}$.

Co oczywiste, towarzyszy temu zjawisko intensyfikacji aktywności zorganizowanych grup przestępczych w zakresie produkcji i obrotu wspomnianymi substancjami. Proceder ten ma wyraźnie transgraniczny charakter, związany $z$ istnieniem międzynarodowych struktur podziemnych laboratoriów oraz sieci kurierskich, realizujących produkcję oraz dystrybucję takich substancji zabronionych ${ }^{35}$. Prócz powiązań ze światem sportu, w tym trenerami, lekarzami sportowymi czy działaczami sportowymi, kanały ich wprowadzania do obrotu prowadzą wprawdzie przez punkty apteczne, gabinety lekarskie, kliniki i szpitale, dostawców suplementów sportowych oraz sprzedaż on-line ${ }^{36}$, niemniej jednak do głównych ośrodków dystrybucji tych substancji, których używanie pozostaje

${ }^{31}$ Zob. Image and Performance, s. 16.

32 Ibidem, s. 7.

33 Zob. L. Paoli, A. Donati, The supply, s. 9-10.

34 Por. Organised crime and drugs in sport. New Generation Performance and Image Enhancing Drugs and Organised Criminal Involvement in their use in Professional Sport, Canberra 2013, s. 12, https://www.ssaa.org.au/wp-content/uploads/2020/09/2013-02_acc-organised-crime-and-drugs-in-sport.pdf (dostęp: 1.07.2021 r.).

35 Zob. A. Michalska-Warias, Przestępczość zorganizowana a sport $w$ świetle badań kryminologicznych, w: Sport a przestępczość zorganizowana, red. M. Leciak, Warszawa 2018, s. 17-19.

36 Zob. Organised crime, s. 22; D. Hughes, Organised crime and drugs in sport: did they teach us about that in medical school?, „British Journal of Sports Medicine" 2013, No. 11, s. 661. 
wciąż najbardziej rozpowszechnione, czyli sterydów i hormonów, należą siłownie i kluby fitness ${ }^{37}$. Problem ten eksponowano w literaturze już kilka dekad temu ${ }^{38}$.

Zaangażowanie zorganizowanej przestępczości wiąże się jednocześnie $z$ faktem, że w obszarze produkcji i obrotu image enhancing drugs możliwe jest wykorzystanie wiedzy i technologii właściwych w tym zakresie do wytwarzania i dystrybucji narkotyków oraz innych grup substancji zabronionych w sporcie. Zakwalifikowanie tego typu działalności w kategoriach low risk - high profits ${ }^{39}$ jest uzasadnione także niewielkim ryzykiem wykrycia oraz częstokroć niskim zagrożeniem karnym wobec traktowania związanych $z$ tym procederem zachowań jako przestępstw farmaceutycznych bądź dotyczących dopingu w sporcie. Dodatkowo wystarczy tylko wspomnieć $z$ jednej strony o wzrastającym gwałtownie na świecie popycie na tego rodzaju środki, $z$ drugiej zaś o niskich kosztach ich produkcji ${ }^{40}$.

37 Zob. L. Paoli, A. Donati, The Sports Doping Market. Understanding Supply and Demand, and the Challenges of Their Control, New York 2014, s. 85 i n.; J. Lowther, Effectiveness, proportionality and deterrence. Does criminalizing doping deliver?, w: Routledge Handbook of Drugs and Sport, eds. V. Moller, I. Waddington, J. Hoberman, Abingdon 2015, s. 342; Pharmaceutical Crime and Organized Criminal Groups. An analysis of the involvement of organized criminal groups in pharmaceutical crime since 2008 - Report, Interpol 17.02.2014, s. 4 i n.

38 Zob. A. Zwierzyńska-Chlebowska, Analiza wybranych przypadków dopingu w sporcie - przestępczość zorganizowana?, w: Sport a przestępczość zorganizowana, red. M. Leciak, Warszawa 2018, s. 86.

39 Por. https://www.interpol.int/Crimes/Corruption/Anti-doping (dostęp: 1.07.2021 r.).

40 Zob. R. Piechota, Zwalczanie nielegalnego handlu substancjami dopingujacymi $w$ prawie międzynarodowym i polityce organizacji międzynarodowych, w: Sport a przestępczość zorganizowana, red. M. Leciak, Warszawa 2018, s. 62; J. Bojsen-Moller, A.V. Christiansen, Use of performance- and image-enhancing substances among recreational athletes: A quantitative analysis of inquiries submitted to the Danish anti-doping authorities, „Scandinavian Journal of Medicine and Science in Sports" 2009, No. 9, s. 861-867. 


\section{Potrzeba i środki reakcji karnej}

Tak nakreślone powyżej zagrożenia, związane $z$ funkcjonowaniem rynku image enhancing drugs, powinny skłaniać do rozważań nad potrzebą reakcji prawnej. Środki profilaktyki społecznej, jakkolwiek podejmowane w wielu krajach, zostały jednak przez wielu ustawodawców krajowych uznane za niewystarczające. Stąd też mechanizmy odpowiedzialności karnej w tym zakresie zostały wdrożone w większości europejskich systemów prawnych. Opierają się one w przeważającej mierze na konstrukcjach typów przestępstw związanych $z$ dopingiem $w$ sporcie, częściowo także przestępstw farmaceutycznych, rzadziej natomiast przestępstw narkotykowych lub tych związanych $z$ bezpieczeństwem żywności.

Poszukując uzasadnienia powołania tego typu instrumentów, można wskazać przede wszystkim na potrzebę ochrony zdrowia publicznego ${ }^{41}$. Stopień zagrożenia dla życia i zdrowia społeczeństwa jest w przypadku tego typu substancji wyjątkowo wysoki. Stąd $\mathrm{w}$ literaturze uwydatnia się potrzebę penalizacji w obrębie takich zachowań jak produkcja oraz obrót nimi i w tym zakresie wskazuje się na analogię do przestępstw narkotykowych ${ }^{42}$.

$\mathrm{Z}$ drugiej strony następstwa zjawiska dopingu, także w sporcie amatorskim lub wszelkich innych formach rekreacji, mogą wiązać się $\mathrm{z}$ zagrożeniem zdrowia publicznego wskutek zmiany postaw społecznych poprzez utratę zainteresowania taką formą aktywności i potrzeby czerpania pewnych wzorców związanych $z$ aktywnym trybem życia. Stąd rola państwa powinna sprowadzać się do niwe-

${ }^{41}$ Na problem ten zwracała wcześniej wyraźnie uwagę Komisja Europejska na gruncie tzw. Białej Księgi na temat Sportu, zalecając, aby we wszystkich krajach UE handel niedozwolonymi środkami dopingującymi traktować w ten sam sposób jak nielegalny obrót narkotykami (zob. Biała Księga na temat Sportu z dnia 11 lipca 2007 r., KOM(2007) 391 wersja ostateczna).

42 Zob. m.in. J. Heshka, The criminality of doping in sport, „International Sports Law Review" 2009, No. 1-2, s. 124 i n.; C. Sumner, The spirit of sport: the case for criminalization of doping in the UK, „International Sports Law Journal” 2017, No. 3-4, s. 120 i n.; L. Paoli, A. Donati, The Sports Doping, s. 86 i n. 
lowania tego rodzaju odbioru i podtrzymywania społecznie ważnej funkcji aktywności sportowej ${ }^{43}$.

Szczególnie istotne wydaje się jednocześnie dostrzeżenie, że w przypadku omawianych kategorii substancji narażone na niebezpieczeństwo pozostawać także może bezpośrednio życie i zdrowie jednostki. Problem ten zdaje się nabierać jeszcze większego znaczenia, gdy przypomni się, że używanie image enhancing drugs dotyczy przeważnie osób młodych, którym prawo karne częstokroć stara się zapewnić szczególną ochronę. W tym zakresie wskazuje się zresztą na możliwe zaangażowanie instrumentów prawa karnego celem ochrony młodych ludzi przed demoralizacją i negatywnym wpływem omawianego zjawiska ${ }^{44}$. Podkreśla się jednocześnie, że sport oraz inne formy aktywności powinny realizować wychowawcze funkcje w odniesieniu do młodych ludzi, a prawo karne może być tego swoistym gwarantem ${ }^{45}$.

Zwraca się także uwagę na potrzebę zabezpieczenia interesów ekonomicznych jako uzasadnienie kryminalizacji pewnych zachowań dotyczących image enhancing drugs. Nie ma przecież wątpliwości, że nielegalna ich produkcja czy obrót nimi mogą narażać Skarb Państwa na znaczne straty ${ }^{46}$. Wskazuje się nawet, że niektóre $\mathrm{z}$ nich da się ująć $\mathrm{w}$ ramy tzw. white collar crimes. Takie osoby jak m.in. lekarze, farmaceuci, właściciele i menadżerowie siłowni czy klubów fitness, wykorzystując swój status zawodowy, nierzadko popełniają przestępstwa związane $z$ dopingiem, np. dostarczając sterydy ${ }^{47}$.

Nie bez znaczenia zdaje się również pozostawać argument odwołujący się do potrzeby zabezpieczenia zasad prawidłowego i wiarygodnego obrotu image enhancing drugs. Trzeba wszakże

43 Zob. M. Leciak, Przestępstwa zwiazane $z$ dopingiem $w$ sporcie - uwagi przy wsparciu analizy prawnoporównawczej, w: Prawo sportowe, red. D. Wetoszka, Warszawa 2018, s. 71.

44 Zob. C. Sumner, op.cit., s. 220-221.

45 Zwraca się na to uwage m.in. w Preambule do Konwencji Antydopingowej UNESCO oraz w art. 18 Światowego Kodeksu Antydopingowego.

46 Por. M. Iwański, Przestępstwo dopingu (art. 50 ustawy o sporcie), „Państwo i Prawo" 2011, nr 7-8, s. 102.

47 Zob. L. Paoli, A. Donati, The Sports Doping, s. 98. 
pamiętać, że znaczna ich część może być przedmiotem legalnej produkcji oraz dystrybucji, oczywiście przy spełnieniu określonych prawem przesłanek. Brak ich realizacji może jednocześnie prowadzić do naruszenia interesów nabywców takich substancji jako konsumentów poszukujących produktów bezpiecznych dla ich życia i zdrowia ${ }^{48}$.

Niezwykle doniosłe znaczenie należy wreszcie przypisać okolicznościom wskazującym na znaczne zaangażowanie zorganizowanych grup przestępczych na całym świecie w obrębie produkcji i dystrybucji tego typu substancji, o czym była już wcześniej mowa.

Powyższe względy zdecydowały o tym, że w większości państw europejskich uchwalono w ostatnich latach szczególne regulacje karne, których celem jest zwalczanie m.in. przestępstw związanych $z$ image enhancing drugs. Ich charakter $-z$ perspektywy rozwiązań krajowych - bywa zróżnicowany i obejmuje $z$ jednej strony zachowania związane $z$ nielegalną produkcją, wprowadzaniem do obrotu czy dystrybucją takich substancji, $z$ drugiej natomiast różne formy udostępniania lub udzielania ich innym osobom, w tym częstokroć małoletnim. Rozwiązania tego typu przewidziano m.in. w Austrii ${ }^{49}$, w Chorwacji ${ }^{50}$, w Estonii ${ }^{51}$, w Finlandii ${ }^{52}$, we Francji ${ }^{53}$, w Hiszpanii ${ }^{54}$,

48 Zob. L. Wilk, w: Komentarz do niektórych przepisów - Prawo farmaceutyczne, w: Pozakodeksowe przestępstwa przeciwko zdrowiu. Komentarz, red. M. Mozgawa, Warszawa 2017, s. 255 i n.

49 Przepisy § 28-29 austriackiej ustawy antydopingowej $z$ dnia 22 grudnia 2020 r. (Bundesgesetz zur Verhinderung von Doping im Sport, BGBl. I Nr. 152/2020).

50 Przepisy art. 190 ust. 1-10 i art. 191 ust. 1-5 Kodeksu karnego Chorwacji $z$ dnia 26 października 2011 r. (Dz.U. 71-05-03/1-11-2).

51 Przepisy $\S 195$ ust. 1-3 Kodeksu karnego Estonii $z$ dnia 5 czerwca 2001 r. (RT I 2001, 61, 364).

52 Przepisy rozdziału 44 Kodeksu karnego Finlandii $z$ dnia 19 grudnia 1889 r. (Nr 39, ze zm.).

53 Przepisy karne Code du sport. Jego powołanie wynika $z$ art. 84 ustawy nr 2004-1343 z dnia 9 grudnia 2004 r. o uproszczeniu prawa.

54 Przepisy art. 362 (5-6) Kodeksu karnego Hiszpanii (Ley Orgánica 10/1995, del Código Penal z dnia 23 listopada 1995 r.). 
na Litwie ${ }^{55}$, w Niemczech ${ }^{56}$, w Rosji ${ }^{57}$, w Słowenii ${ }^{58}$, w Szwajcarii ${ }^{59}$, we Włoszech ${ }^{60}$.

$\mathrm{Na}$ reakcję karną zdecydował się również polski ustawodawca. W obrębie regulacji art. 48 ust. 1-2 i art. 49 ust. 1-3 ustawy antydopingowej poddano karalności: podawanie małoletniemu zawodnikowi substancji zabronionej określonej w grupie S1, S2 lub S4 załącznika nr 1 do Konwencji antydopingowej UNESCO; podawanie ww. substancji zawodnikowi bez jego wiedzy; udostępnianie osobom trzecim, odpłatnie lub nieodpłatnie, ww. substancji lub przechowywanie jej w celu udostępnienia osobom trzecim, odpłatnie lub nieodpłatnie, bez pozwolenia na dopuszczenie do obrotu wydanego na podstawie art. 3 ust. 1 lub ust. 2 Ustawy $z$ dnia 6 września 2001 r. - Prawo farmaceutyczne ${ }^{61}$; prowadzenie obrotu ww. substancją bez zezwolenia, o którym mowa w art. 70 ust. 4, art. 74 ust. 1 lub art. 99 ust. 1 ustawy - Prawo farmaceutyczne; przywożenie lub sprowadzanie na terytorium Rzeczypospolitej Polskiej ww. substancji w sposób niezgodny z art. 68 ustawy - Prawo farmaceutyczne. Jak już wspomniano, zakres penalizacji na gruncie art. 48-49 ustawy antydopingowej odnosi się więc wyraźnie do tych substancji, które można zaliczyć do kategorii image enhancing drugs. Chodzi bowiem właśnie o środki anaboliczne (S1), hormony peptydowe, czynniki wzrostu, substancje pokrewne i mimetyki (S2); modulatory hormonów i metabolizmu (S4). Jak się zdaje, w ten sposób przyznano wyraźny prymat potrzebie karania sprawców

55 Przepisy art. 160, 199 i 276 $1-267^{3}$ Kodeksu karnego Litwy z dnia 26 września 2000 r. (Nr VIII-1968).

56 Przepisy karne niemieckiej ustawy antydopingowej $z$ dnia 10 grudnia 2015 r. (Anti-Doping-Gesetz, BGBl, I S. 2210).

57 Przepisy art. 230'-230² rosyjskiego Kodeksu karnego z dnia 13 czerwca 1996 r. (Nr 63-FZ).

58 Przepisy art. 186-187 Kodeksu karnego Słowenii z dnia 4 czerwca 2008 r. (Kazenski zakonnik, Uradni list RS, št. 55/08).

59 Przepisy art. 22 ust. 1-4 ustawy $z$ dnia 17 czerwca 2011 r. o promocji sportu (Bundesgesetz über die Förderung von Sportund Bewegung, SR 415).

60 Przepis art. 586 bis Kodeksu karnego Włoch z dnia 19 października 1930 r. (Regio Decreto n. 1398, Approvazione del testo definitivo del Codice Penale).

61 Dz.U. Nr 126, poz. 1381 ze zm. 
tych tylko zachowań, które dotyczą substancji stwarzających najpoważniejsze zagrożenie dla życia i zdrowia człowieka. Na taki argument zwraca zresztą uwagę sam projektodawca wspomnianych przepisów karnych ustawy antydopingowej62.

Dodatkowo nie jest wykluczona odpowiedzialność karna sprawcy na podstawie przepisów karnych art. 124 i nast. ustawy - Prawo farmaceutyczne, podobnie jak na podstawie regulacji Kodeksu karnego (np. art. 155-160 k.k.).

\section{Podsumowanie}

Nie powinno być wątpliwości co do tego, że używanie image enhancing drugs należy traktować w kategoriach problemu społecznego wymagającego zdecydowanej reakcji prawnej, w tym karnoprawnej. Aktualnie jest ona oparta w większości ustawodawstw europejskich na szczególnych regulacjach typizujących przestępstwa związane $\mathrm{z}$ dopingiem $\mathrm{w}$ sporcie. W niektórych państwach, np. w Wielkiej Brytanii, opiera się natomiast na konstrukcji przestępstw farmaceutycznych lub związanych $z$ bezpieczeństwem żywności. Kluczowe dla skutecznej walki $z$ tym zjawiskiem, którego skutki mogą okazać się wyjątkowo dotkliwe dopiero w dłuższej perspektywie czasu, wraz $z$ pojawieniem się niepożądanych następstw zdrowotnych nadużywania wspomnianych substancji najczęściej przez młode osoby, wydaje się $z$ jednej strony podjęcie szerokiej profilaktyki społecznej, $z$ drugiej zaś zapewnienie skutecznego ścigania karnego, w szczególności w zakresie zachowań związanych $z$ produkcją oraz dystrybucją tych środków. To $z$ kolei wymaga funkcjonowania wyspecjalizowanych służb, których jak dotąd nie powołano zarówno w Polsce, jak i w większości innych państw. Przeszkodą może przy tym okazać się fakt, że mimo skali omawianego zjawiska zaangażowanie $\mathrm{w}$ walkę $\mathrm{z}$ dopingiem $\mathrm{w}$ sporcie po stronie takich podmiotów jak agencje antydopingowe czy federacje sportowe, a jednocześnie współpraca między nimi a krajowymi

62 Zob. Uzasadnienie rządowego, s. 24-27. 
organami ścigania oraz Interpolem obejmują przede wszystkim określone zachowania w sporcie profesjonalnym, co prowadzi tym samym do marginalizacji omawianych w tym opracowaniu problemów i potrzeby właściwej reakcji na nie.

\section{STRESZCZENIE}

Image enhancing drugs w sporcie - analiza zjawiska i karnoprawnych środków jego zwalczania

Zjawisko dopingu w sporcie amatorskim oraz uprawianym rekreacyjnie jest marginalizowane. Jego zasięg jest jednak większy aniżeli w sporcie profesjonalnym. Wynika to $z$ ciągłego wzrostu liczby przypadków stosowania sterydów, hormonów oraz innych substancji zabronionych, najczęściej przez osoby uczęszczające na siłownię i do klubów fitness. Cel ich używania nie wiąże się przy tym $z$ chęcią osiągnięcia określonego wyniku sportowego. Dotyczy bowiem przede wszystkim poprawy wyglądu zewnętrznego. Procederowi temu towarzyszy zainteresowanie zorganizowanej przestępczości w zakresie produkcji i dystrybucji takich środków. Taki jego charakter wymusza potrzebę zdecydowanej reakcji karnej oraz zaangażowania odpowiednio przeszkolonych służb i agend państwowych.

Słowa kluczowe: sport; doping; sterydy; hormony; zdrowie publiczne; przestępstwo

\section{SUMMARY}

Image enhancing drugs in sport - analysis of the phenomenon and criminal law measures to combat it

The phenomenon of doping in amateur and recreational sports is marginalized. However, its scope is greater than in professional sports. This is due to the fact that the use of steroids, hormones and other prohibited substances is constantly increasing, most often by people who attend gyms and fitness clubs. The purpose of their use is not related to the desire to achieve a specific sports result. It is mainly aimed at improving one's physical appearance. This practice is accompanied by the interest 
of organized crime in the production and distribution of such drugs. Its nature requires a strong criminal reaction and the involvement of properly trained state services and agencies.

Keywords: sport; doping; steroids; hormones; public health; crime

\section{BIBLIOGRAFIA}

Bojsen-Moller J., Christiansen A.V., Use of performance- and image-enhancing substances among recreational athletes: A quantitative analysis of inquiries submitted to the Danish anti-doping authorities, „Scandinavian Journal of Medicine and Science in Sports” 2009, No. 9, https:// doi.org/10.1111/j.1600-0838.2009.01023.

Cadwallader A.B., de la Torre X., Tieri A., Botrè F., The abuse of diuretics as performance-enhancing drugs and masking agents in sport doping: pharmacology, toxicology and analysis, „British Journal of Pharmacology" 2010, No. 1, https://doi.org/10.1111/j.1476-5381.2010.00789.

Duntas L.H., Popovic V., Hormones as doping in sports, „Endocrine” 2012, No. 2, https://doi.org/10.1007/s12020-012-9794-9.

Haas U., Background to the World Anti-Doping Code 2015, w: Doping in sport and the law, eds. U. Haas, D. Healey, Oxford 2016.

Hauw D., Bilard J., Understanding Appearance-Enhancing Drug Use in Sport Using an Enactive Approach to Body Image, „Frontiers in Psychology” 2017, No. 8, https://doi.org/10.3389/fpsyg.2017.02088.

Heshka J., The criminality of doping in sport, „International Sports Law Review" 2009, No. 1-2.

Hildebrandt T.B., Varangis E., La J.K., Appearance and Performance Enhancing Drug Use, w: The Oxford Handbook of Sport and Performance Psychology, ed. S.M. Murphy, Oxford 2012, https://doi.org/10.1093/ oxfordhb/9780199731763.001.0001.

Hughes D., Organised crime and drugs in sport: did they teach us about that in medical school?, „British Journal of Sports Medicine” 2013, No. 11, https://doi.org/10.1136/bjsports-2013-092570.

Image and Performance Enhancing Drugs. UKAD status report on IPEDs in the UK, London 2019, https://www.ukad.org.uk/sites/default/ files/2020-01/UKAD\%20IPED\%20Report\%20FINAL.pdf.

Iwański M., Przestępstwo dopingu (art. 50 ustawy o sporcie), „Państwo i Prawo" 2011, nr 7-8. 
Karazsia B.T., Crowther J.H., Galioto R., Undergraduate men's use of performance- and appearance-enhancing substances: An examination of the gateway hypothesis, „Psychology of Men \& Masculinity” 2012, No. 2, https://doi.org/10.1037/a0027810.

Kremenik M., Onodera S., Nagao M., Yuzuki O., Yonetani S., A historical timeline of doping in the Olympics (Part I 1896-1968), „Kawasaki Journal of Medical Welfare" 2006, No. 1.

Leciak M., Przestępstwa związane z dopingiem w sporcie - uwagi przy wsparciu analizy prawnoporównawczej, w: Prawo sportowe, red. D. Wetoszka, Warszawa 2018.

Lowther J., Effectiveness, proportionality and deterrence. Does criminalizing doping deliver?, w: Routledge Handbook of Drugs and Sport, eds. V. Moller, I. Waddington, J. Hoberman, Abingdon 2015, https://doi. org/10.4324/9780203795347-28.

Lusetti M., Licata M., Siligardi E., Bonsignore A., Palmiere C., Appearance/ Image- and Performance-Enhancing Drug Users. A Forensic Approach, „The American Journal of Forensic Medicine and Pathology” 2018, No. 4, https://doi.org/10.1097/paf.0000000000000424.

Łuczak M., Doping in Sport: The Case of Fencing, „Central European Journal of Sport Sciences and Medicine” 2016, No. 1, https://doi. org/10.18276/cej.2016.1-14.

Martínez-Sanz J.M., Sospedra I., Mañas Ortiz 3 Ch., Baladía E., Gil-Izquierdo A., Ortiz-Moncada R., Intended or Unintended Doping? A Review of the Presence of Doping Substances in Dietary Supplements Used in Sports, „Nutrients” 2017, No. 9, https://doi.org/10.3390/nu9101093.

Mazzeo F., Ascione A., Anabolic androgenic steroids and doping in sport, „Medicina Sportiva. Journal of the Romanian Sports Medicine Society” 2013, No. 1.

Mędras M., Jóźków P., Zastosowanie testosteronu i steroidów androgenno-anabolicznych $w$ sporcie, „Polish Journal of Endocrinology” 2009, nr 3.

Michalska-Warias A., Przestępczość zorganizowana a sport $w$ świetle badań kryminologicznych, w: Sport a przestępczość zorganizowana, red. M. Leciak, Warszawa 2018.

Mooney R., Simonato P., Ruparelia R., Roman-Urrestarazu A., Martinotti G., Corazza O., The use of supplements and performance and image enhancing drugs in fitness settings: A exploratory cross-sectional investigation in the United Kingdom, „Human Psychopharmacology: Clinical and Experimental” 2017, No. 3, https://doi.org/10.1002/hup.2619. 
Müller R.K., History of doping and doping control, w: Doping in Sports, eds. D. Thieme, P. Hemmersbach, Berlin 2010, https://doi.org/10.1007 /978-3-540-79088-4_1.

Organised crime and drugs in sport. New Generation Performance and Image Enhancing Drugs and Organised Criminal Involvement in their use in Professional Sport, Canberra 2013, https://www.ssaa.org.au/wp-content/ uploads/2020/09/2013-02_acc-organised-crime-and-drugs-in-sport. pdf.

Paoli L., Donati A., The Sports Doping Market. Understanding Supply and Demand, and the Challenges of Their Control, New York 2014, https:// doi.org/10.1007/s12117-014-9238-4.

Paoli L., Donati A., The supply of doping products and the potential of criminal law enforcement in anti-doping: an examination of Italy's experience, Leuven 2013.

Pharmaceutical Crime and Organized Criminal Groups. An analysis of the involvement of organized criminal groups in pharmaceutical crime since 2008 - Report, Interpol 17.02.2014.

Piechota R., w: Prawo sportowe, red. M. Leciak, Warszawa 2018.

Piechota R., Reguły antydopingowe $w$ prawie międzynarodowym, „Studia Iuridica Toruniensia” 2010, nr 6.

Piechota R., Zwalczanie nielegalnego handlu substancjami dopingujacymi $w$ prawie międzynarodowym i polityce organizacji międzynarodowych, w: Sport a przestępczość zorganizowana, red. M. Leciak, Warszawa 2018.

Przybylski Z., Medyczne aspekty dopingu w sporcie, w: Prawne problemy dopingu w sporcie, red. A.J. Szwarc, Poznań 1992.

Sas-Nowosielski K., Doping nie tylko w sporcie. Przyczyny. Skutki. Przeciwdziałanie, Katowice 2002.

Sumner C., The spirit of sport: the case for criminalization of doping in the UK, „International Sports Law Journal” 2017, No. 3-4, https://doi. org/10.1007/s40318-016-0103-2.

Wach A., Harmonizacja światowego prawa antydopingowego z polskiej perspektywy, „Państwo i Prawo” 2007, nr 8.

Wach A., Swiatowy Kodeks Antydopingowy - aspekty prawne, „Sport Wyczynowy" 2003, nr 7-8.

Wilk L., w: Komentarz do niektórych przepisów - Prawo farmaceutyczne, w: Pozakodeksowe przestępstwa przeciwko zdrowiu. Komentarz, red. M. Mozgawa, Warszawa 2017.

Zwierzyńska-Chlebowska A., Analiza wybranych przypadków dopingu $w$ sporcie - przestępczość zorganizowana?, w: Sport a przestępczość zorganizowana, red. M. Leciak, Warszawa 2018. 